\title{
Research on Training of Talents in Cultural and Smart Product Design Based on Cooperative Education*
}

\author{
Lie Wang \\ School of Fine Arts and Design \\ Guangzhou University \\ Guangzhou, China
}

\author{
Jie Luo \\ School of Fine Arts and Design \\ Guangzhou University \\ Guangzhou, China
}

\begin{abstract}
The vigorous development of the cultural and creative industry has led to a large increase in the demand for cultural and creative product design talents. Many colleges and universities have set up cultural and creative design majors. However, with the change in consumers' demand, traditional cultural and creative products are in need of reform because of their monotonous and homogenous functions. As a new hot spot in the consumer market, smart products have been sought after by the cultural and creative industry in recent years. However, the current modes for cultivating such comprehensive talents in universities are still not perfect. This article starts with the current situation of the training of talents in cultural and intelligent product design, combining with the teaching experience accumulated in recent years, proposes a new idea of fostering the talents in cultural and intelligent product design based on the school-enterprise synergy education, taking the "practice, construction, examination, evaluation" as the approach.
\end{abstract}

Keywords-cultural and creative product design; intelligent product design; school-enterprise synergy education

\section{INTRODUCTION}

Industry 4.0 has become the important development trend of China's manufacturing industry in the next 30 years. The Chinese government released the "Made in China 2025" strategic plan, which emphasizes the application of smart manufacturing technology. Smart Manufacturing integrates manufacturing and the information technology, which is used in many industries. The Chinese government also emphasizes that smart manufacturing should be the main target of the "Made in China 2025", the research, development and production of smart products should be focused on, the development and industrialization of smart products such as wearable products, smart appliances, and service robots should be sped up. At the same time, it was stated in the government work report that the government must adhere to take the

*Fund Information:

Supported by the Ministry of Education Humanities and Social Science Research General Project Engineering Science and Technology Talent Cultivation Special Item, Project Number: 17JDGC021

Supported by Guangzhou University Teaching Research Project "Study on the Training Model for Cultural and Creative Smart Product Design Talents in the Face of "China Manufacturing 2025" " , Item No.: JY201837 supply-side structural reform as the main line, focus on cultivating and expanding new kinetic energy, and accelerate the optimization and upgrading of the economic structure. Therefore, in terms of cultural creativity, unlike the mass and extensive consumption in the past, today's consumption of cultural products has become more personalized and diverse. The consumer market is constantly undergoing transformation and upgrading, and people are more willing to spend money on good things even if they have high prices. For example, Cheng Xinxiang, a representative of National People's Congress and the director of Xinlei embroidery department in Hunan Provincial Embroidery Research Institute, demonstrated a fingerprint-encrypted embroidery notebook in an interview, which was designed and manufactured using special embroidery craftsmanship combined with modern intelligent manufacturing methods. It has got a lot of praise since it was put into the market, and it makes the traditional culture be used in modern life. It has been proved by facts that with the release of "Made in China 2025" plan, the cultural creative industry ushered in the spring breeze of development and reform, many cultural and creative enterprises have turned their research and development direction to designing and producing cultural and intelligent products according to the new demands of consumers. Guangdong, as a pilot region of the country, has a complete system of intelligent product design and manufacture and has also cultivated a large number of outstanding cultural and creative enterprises. These emerging companies have provided many work opportunities for design students in Guangdong's universities. Take our department as an example, more than $80 \%$ of graduates' working places in recent years are cultural and creative enterprises, and over $70 \%$ of industrial product design graduates work in the smart product design industry. In order to respond to the country's development plan, colleges should carry out education focusing on the needs of employers and adopt the schoolindustry cooperative education model.

\section{Cultural and Creative Product Design Is Hot in CURRENT DESIGN EDUCATION}

For China's industrial product design majors, cultural and creative product design has become a brand-new and fastdeveloped design major. In recent years, many domestic first- 
rate undergraduate colleges have set up the cultural and creative product design major or experimental classes. Different from past tourism product design and souvenir design, cultural and creative product design focuses more on

"culture" and "innovation". Professor Wei Pengju, the Executive Dean of the Center for Cultural and Creative Research of Central University of Finance and Economics, pointed out in the "Attributes and Characteristics of Cultural and Creative Products": "Cultural and creative products refer to any product or combination of products produced in the cultural and creative industry. In terms of the final forms of products, cultural and creative products contain two interdependent parts: cultural and creative content and hardware carriers. The main difference between cultural creative products and other general products is that cultural products have the cultural and creative content, which is the core value of cultural and creative products. However, cultural and creative content cannot exist independently and must rely on specific hardware carriers."[1] At the same time, the "culture" of cultural and creative products involves a wide range. From traditional craftsmanship to folk customs, from modern manufacturing to fashion trends, and from intangible cultural heritage to 3D printing, the "culture" of cultural and creative products covers every aspect of people's lives. The "innovation" is to use the appropriate way, carrier, and technology to make the seemingly ordinary "culture" around us appear in a new, delightful, and materialized form. And the "culture" can be spread through this "material".

Zhang Yin of Fashion Design Department of Wenzhou Vocational and Technical College stated in the Preliminary Study on the Development of Cultural and Creative Products Based on the Artistic Features of "Intangible Cultural Heritage": "Cultural and creative products need to be designed with cultural connotations as the inspiration. The design should break through the simple replication of cultural surfaces. It should make people aware of the cultural genes contained in the products and eventually reach the goal of cultivating people with culture. The development mode of cultural and creative products just coincides with the tangible material protection of intangible cultural heritage, and through the spread of cultural and creative products, the intangible cultural heritage is integrated into the daily life of modern people in material forms. This will play a significant role in the protection and heritage of 'intangible cultural heritage'." [2]With regard to the current heritage and innovation of intangible cultural heritage and cultivation for cultural and creative design talents, experts in colleges and universities have their own unique views. As early as in 2005, Prof. Chen Hanqing argued that "Only by placing the inheritance and innovation of intangible cultural heritage under the trend of international design, interpreting Chinese local culture in a global perspective, combining modern design science with traditional culture, technology with art, and using the information technology, digital technology, and modern design means at the same time, can we maximize the protection, development, inheritance and innovation of intangibles. And in turn, it can also promote the development of modern design and cultural creative industries in China."[3] After nearly a decade of development, the society has become informationbased and data-based, giving us modern people a lot of new experiences. These experiences have not only led to new demands of consumers, but also brought new inspiration and creativity to designers. Therefore, Professor Song Jianming pointed out in his thesis that "from the perspective of cultural and creative design, using the unique image thinking method to coordinate the wisdom of science technology and economics will help to solve the problems we are facing"[4].As a result, more and more scholars have put forward their views on the cultivation of intangible heritage cultural creative design talents from an interdisciplinary perspective. Associate Professor Zhang Ming of School of Industrial Design of Nanjing University of Arts believes that "in the cultivation of talents, we must strengthen students' understanding of modern design concepts, make them understand contemporary aesthetics and international design trends, require them not only to correctly use traditional cultural elements, but also profoundly understand the core connotation of intangible heritage projects. The training mode cannot be only a superposition of knowledge, and colleges and universities should aim at cultivating comprehensive talents and always use the modern design ideology to guide the creative continuation of the intangible heritage." [5] With these famous scholars' great efforts, cultural creative design education and the inheritance and innovations of intangible heritage have gone out of classes in colleges and universities and become a new hot spot in current design education.

With the publication and implementation of national policies which support the cultural and creative industry, and under the leadership of the government, many cultural organizations such as Guangdong Provincial Intangible Heritage Protection Center and Guangdong Provincial Museum have organized creative product contests jointly with colleges to find more innovative product designs and talents. At the same time, with the organization of these events, many universities and colleges have also initiated research on cultural and creative product design. In these cultural and creative activities, innovative designs aiming at promoting or inheriting a specific "culture" are conducted in the "multidisciplinary and cross-professional" form. For example, in the cultural and creative activity with the theme of Nanyue Ancient Road, the design teams formed by various universities come from different majors: humanities research, product design, visual communication, environmental arts, and so on. Although members in design teams have different ways of thinking and working, their ideas can collide to produce more novel and feasible designs in the process of cultural topic study. These designs have gained the attention of enterprises while being promoted and protected by the government media, and many designs have been realized. As the cultural and creative industry market is expanding, colleges and universities, as training bases for design talents, have to undertake the responsibility to conduct education on market hot spots. Therefore, in areas where cultural resources are abundant and the cultural and creative industry started early, many colleges and universities in recent years have established the cultural and creative product design major to adapt to the expanding employment market and form the characteristics of them. 


\section{SMART PRODUCT Design Is THE NEW DiRECTION OF CUltural AND CREATIVE DESIGN}

Traditional cultural and creative products are mostly the products with visual design as the core, such as postcards, keychain, fridge magnets, and so on. As people's life is becoming more and more abundant, these stereotyped products can no longer satisfy people's pursuit of materialized cultural feelings. The cultural and creative industry is facing the pressure of transformation while it is developing rapidly. The traditional "labeling" development process of firstly designing a set of visual images and then widely applying it into products is no longer in line with the development trend. The forms of modern cultural and creative products are more flexible and diverse. In addition to traditional tourist souvenirs, thematic gifts, personal life supplies, and intelligent software have all become the carriers of cultural creativity. The vigorous and diversified development of the cultural and creative industries has formed a virtuous circle, which not only enriches the product market but also makes excellent culture deeply rooted in the hearts of the people. For example, Dr. Wang Weiwei and his team of Shaanxi University of Science and Technology, through the in-depth analysis of the core ideas in Chinese health culture, using the research method of design genes, extracted elements of health culture and visualized them. They integrated the health culture into the design of smart products combining with the design features of smart watches, reflecting the unique wisdom of Chinese culture and providing new ideas for the design of wearable devices. [6] Another example is that Li Liping and his team of Beijing University of Information Science and Technology applied intelligent hardware to the design of creative products of traditional Dongba culture. They utilized the interactive and interesting nature of intelligent hardware and combined the eight-chart diagram which was a representative of Dongba's traditional culture, and finally designed and developed a "lazy" clock based on the open source hardware Arduino technology. The clock takes the Dongba eight-chart diagram as the dial, and the design emphasizes the interaction between the user and the "lazy" clock. If the user approaches the clock, the middle pointer will start to rotate. If the user leaves, the pointer will stop rotating. Whether the pointer rotates or not will not affect the normal display of time. The design breaks through the monotony and pure decoration function of traditional cultural products, making users have "fun" as well as promoting the traditional Dongba culture. [7] The users of cultural creative smart products are mostly "new generations". The information they receive in daily life is diversified. Compared with the "predecessors" who attach importance to the tradition, the "new generations" pay more attention to the cultural connotation and innovative features of products. In recent years, the author has led students to carry out many thematic cultural and creative design activities. Many of the design works in these activities are smart products. An on-board smart assistant with the theme of "Nanyue Awakening Lion" gained a lot of praise from the society. This product is inspired by the emotional state on the lion's head. The lion's head is used as the basic model. Human-computer interaction is achieved through the opening and closing, flickering and other effects of the eyes: such as boot prompts, operation feedback, and game interaction. The navigation display is placed under the lion's head in the form of a tongue, which allows for flexible folding and shows a lively and vibrant image of the product. Using the vehicle-mounted product as the carrier for the "Nanyue Awakening Lion" can, on the one hand, inspire the spirit of the driver, on the other hand, show "positive energy" in the city's crowded traffic environment and have positive influence on the driver's emotion.[8] As the designs favored by modern consumers, these smart product designs have been introduced into more and more designs of cultural and creative products.

In the current undergraduate education, traditional cultural and creative product design is characterized by simple structure and function, small-batch manufacturing, and the embodiment of traditional craftsmanship. However, the product's service life is short, the amount of consumers is small, the cost is unstable, and the competition among enterprises is fierce, leading to the industry' s high mobility. Thanks to the spring breeze of China's intelligent manufacturing, many cultural and creative companies have turned their attention to smart products and have conducted indepth cooperation with traditional product design majors. At present, although many domestic universities and colleges have set up cultural and creative majors, they lack the background of smart product design and cannot provide excellent talents who can meet the needs of society. Many available cultural creative smart products are produced through the long-term exploration and cross-industry cooperation of companies. For example, it was mentioned above that the Xiang embroidery computer was jointly developed by the consumer electronics design and manufacturing enterprise and Xiang Embroidery Institute. Other cultural creative smart products are the research results of scientific research teams in colleges and universities. The meaningful products like the ones mentioned above are all innovations made by the design teams by taking product design and development as the stand and using "culture" as the source of modeling. The number of successful cases is very small, and they are extremely concerned by the market, which shows that the shortcoming of the current cultural and creative design education is the training of intelligent product design talents.

\section{SCHOOL-ENTERPRISE SYNERGISTIC EDUCATION FOR Cultural AND CReative InTElLigent PRoduct DESIGN TALENTS}

The most effective way to train cultural and creative intelligent product design talents in colleges and universities is to conduct school-enterprise synergistic education. Especially in comprehensive universities, because the schools themselves have interdisciplinary resources, coupled with the support of local economies, it is relatively easy to form such talent cultivation atmosphere.

The implementation of school-enterprise synergy education for cultural creative intelligence product design talents in comprehensive colleges can be carried out in the following four steps:

The first step: case study. For some of the design students, the project-based practical teaching activities are carried out on the basis of the existing teaching system, which require them to make a series of cultural and creative intelligent product 
designs. Observe how they obtain cultural and creative inspiration through existing learning resources, how they conduct multi-disciplinary cooperation, and how they finally design and manufacture smart products.

The second step: model construction. Through the study of the above-mentioned practice results, try to extract a set of training ideas that combine classroom teaching and extracurricular practice, and find suitable course modules to conduct experiments.

The third step: the effect evaluation. The teaching results generated in the experimental course modules are introduced into the school-enterprise cooperation project, and the feasibility of the results is verified through business incubation.

The fourth step: cooperative education. The students with better performances in the experimental course modules are selected to form the school-enterprise cooperation project team, and their capabilities of cultural and creative intelligent product design are strengthened through innovative training and short-term internships.

The goal of the education or research conducted in this way is to explore and construct a model suitable for current design teaching through the observation and summary of design and development practices of cultural and creative intelligent products, in order to cultivate cultural and creative intelligent product design talents for enterprises. The difficulties in its implementation lie in how to simultaneously and effectively conduct cultural and creative teaching and intelligent product design teaching; how to guide students to study the implantation of cultural creativity in the intelligent product development thinking and methods; how to combine the rational thinking of intelligent product development and the perceptual thinking of cultural creative design in teaching and practice. Finally, through the cooperation with companies, whether the talents cultivated by this model meet the expected goal is tested.

This model is based on the "constructivism" of contemporary teaching. Since the 1980s, constructivism has become popular and has been known as the "mainstream theory" of educational reform. As a theory to explain "what knowledge is" and "what learning is", constructivism has three aspects of views: knowledge is the individual's active construction, not the passive acceptance or absorption; knowledge reflects individual subjective experience; knowledge is the social construction which has experienced consultation and reconciliation. These basic principles constitute the basis of today's learning theory, affecting the reform process of domestic education, and are also issues that must be considered for constructing "learning-centered" classroom teaching. In this model, new ways of cultivating talents are explored through the study of students' proactive construction of new knowledge systems, and the feasibility of the model is evaluated through social enterprises' inspections. This model is feasible for comprehensive universities which are in the regions where there are cultural and creative industries. Through the teaching activities conducted under this mode, talents from industrial product design and various design majors can have opportunities to participate in specific projects under the guidance of teachers and enterprises. They can learn from and cooperate with each other, and become the excellent talents who have the capability of cultural and creative intelligent product design, which can make universities better serve the society.

\section{CONCLUSION}

In summary, this article explores talent cultivation models combining the society's demand for top-notch talents, and focuses on the common needs for talents of the cultural and creative industry and the intelligent product industry. At the same time, combining the characteristics of comprehensive universities, it has proposed universities to use multidisciplinary resources, form cross-disciplinary student teams, and conduct school-enterprise synergy education. Explore the talent cultivation mode through the practiceconstruction-test-evaluation model. In addition, in the practical teaching activities carried out in this training mode, there may be some products or designs with market prospects, and through the school-enterprise synergy education project, the incubation period of these products or designs can be greatly shortened, thereby improving the self-driving creation ability of universities.

\section{REFERENCES}

[1] Wei Pengju. The Attributes and Characteristics of Cultural and Creative Products[J]. Culture, 2010(8).p.51. 魏鹏举. 文化创意产品的属性与特 征 $[J]$. 文化月刊, 2010（8）.51.

[2] Zhang Yin. A Preliminary Study on the Development of Cultural and Creative Products Based on the Artistic Features of "Intangible Heritage" [J]. Industrial Economics, 2017(5).p.134. 张吟. 基于“非 遗”艺术特色的文化创意产品开发初探 [J]. 产业经济, 2017 (5). 134 .

[3] Chen Hanqing, Cao Yali. Interpretation of the Symbolic Language in Design and Its Local Cultural Connotation [J]. Decoration, 2005 (12). 陈汗青、曹亚丽. 解读设计符号语言及其本土文化内涵 $[\mathrm{J}]$. 装 饰, 2005 (12)

[4] Song Jianming. When the Research Education of "Cultural and Creative Design" Encounters the "Collaborative Innovation" Context, Based on the Thinking of "Art + Science and Technology + Economic Disciplines" Research and Teaching [J]. New Fine Arts, 2013(11).pp.10- 20. 宋建明. 当 “文创设计” 研究性教育遭遇 “协同 创新” 语境基于 “艺术+科技+经济学科” 研与教的思考 $[\mathrm{J}]$. 新美 术, 2013 (11) . 10-20.

[5] Zhang Ming. A New Model for the Cultivation of Cultural Creative Design Talents in the Context of Intangible Heritage Inheritance and Innovation[J]. Heilongiiang Higher Education Research, 2016(12).p.140. 张明. 非遗传承创新语境下的文创设计人才培养新模式 $[\mathrm{J}]$. 黑龙江 高教研究, 2016（12）. 140。

[6] Wang Weiwei, Chen Mengmeng, Liu Yin, Zhang Yujie. Extraction and Application of Design Factors in Traditional Health Culture[J]. Journal of Graphics, 2017(2).pp.52-56. 王伟伟、陈萌萌、刘音、张钰洁. 传 统养生文化中的设计因子提取及应用研究 $[\mathrm{J}]$. 图学学报, 2017 (2) . 52-56.

[7] Li Liping, Jiang $\mathrm{Ke}, \mathrm{Wu}$ Guoxin. Research on Dongba Cultural Intelligent Product Design [J]. Thesis, 2017(5).pp.22-23. 李利苹、姜 可、吴国新. 东巴文化智能产品设计研究 [J]. 论文月刊, 2017 (5) . 22-23.

[8] Wang Lie. The Application of "Intangible Heritage" Elements in Product Design - Taking "Guangdong Awakening Lion " as an Example [J]. Art Review, 2017 (2). pp.177-179. 王茢. “非遗” 元素在产品设 计中的应用-—以“广东醒狮” 为例 [J]. 艺术评论, 2017 (2) . 177-179. 